\title{
TODAY'S LEGAL THINKING AND ITS ECONOMIC IMPACT IN CHINA
}

\author{
GaO XI-ChING* \\ I \\ INTRODUCTION
}

\section{A. A Frog in the Well}

The great philosopher Zhuangzi (600-500 B.C.?) once wrote that a frog's field of vision is much wider than a man's. But, he added, a frog sitting at the bottom of a well can see only a fraction of the sky a man sees. Doing business in China is like trying to see the sky, and the purely business aspect is like the part of the sky one can see from the bottom of a well. If one does not jump out of the well to see the greater sky of China as a whole, then the image seen is incomplete. And if one is from a different culture, the image is apt to be further distorted.

Many people sit in a well created by their own preconceptions, the results of their cultural background, education, philosophical attitude, and overall world outlook. True, one can be very insightful about that part of the sky seen by one's fellow countrymen-but only that part of sky, and only what is seen in their eyes. There are things at least as important outside the well as inside, but a frog in a well does not see them. And there are things that can be seen differently even from inside the well, but this the frog does not know.

In 1972, when President Nixon reached out his hand across the Pacific for Zhou En-Lai's, a sense of euphoria suffused the U.S. business world. Hoping to get an easy share of the gigantic billion people market, a swarm of corporate executives accompanied by their legal counsel landed in China. Many were disappointed. Few among those who felt that they got what they came for succeeded easily. Some six years later, Deng Xiao-Ping started an economic revolution that was unprecedented in the communist world. A new euphoria emerged. New tides of executives, salespersons, bankers, and lawyers appeared, many of them setting aside their bad memories of the last China wave. Once again, however, few got what they had expected.

Doing business can be frustrating anywhere, but businessmen say China is unique. Lawyers and scholars have tried to find out where the conventional wisdom has gone wrong and how to reconstruct it, but frustration with the Chinese Government and potential trading partners continues to permeate

Copyright (C) 1989 by Law and Contemporary Problems

* Assistant Professor of Law, Beijing University of International Business and Economics.

The author would like to express his gratitude to the following people who helped edit and type this article: Professor Jonathan Ocko, Margaret Moody, Dorothy Wang, and Shu-Ya Zhang. 
Sino-American business relationships. More than a decade has passed since Americans renewed their study of China. Those business people and lawyers who deal with China now are better prepared and better equipped-with the language, the law, the various guidelines, name lists, and even self-compiled nationwide yellow page telephone books. ${ }^{1}$ Yet, even these seemingly successful business people and lawyers sometimes feel as if they are treading on eggs, and they show a lack of confidence in their knowledge about the people with whom they are dealing. Why is this?

\section{B. Knowing Oneself and One's Adversary}

Nobody likes to think of himself as the frog in a well, but it is difficult to realize how limited one's perceptions are. It is not only a matter of familiarity with oneself, but also with one's counterparts. In his book The Art of War, Sunzi, a military genius who lived during the Spring and Autumn period of China's history (770-476 B.C.), says, "Know yourself and know your adversary. Then you are invincible." Not only can a business counterpart be an adversary, but one can also be one's own adversary. This is not a cliche. Only by knowing oneself well can one know one's counterpart well, and by knowing him well one can be more confident about his next move and about his response to one's next move.

It is obvious that Chinese culture is different from Western culture, but this does not make Chinese people "inscrutable"2 as some Westerners apparently assume. The Chinese way of thinking and responding is logical and stems from a distinctive cultural background, educational system, social environment, and long-imbedded philosophical attitudes developed over centuries. They are, of course, knowable.

So, let us try to know them.

II

The Lawyers and the Businessmen: Their Educational Background and Behavioral Patterns

Those doing transactions in China will initially be dealing with two groups of people: the legal staff $^{3}$ and the trade personnel. This article will be concerned mainly with their common characteristics, because much of the work done by lawyers in the U.S. is done by businessmen in China, particularly in international business transactions.

The central argument of this article is that it is essential to understand the character of Chinese lawyers and businessmen, and that a sensible way to do this is to categorize them analytically in two ways: vertically by age and horizontally by educational background.

1. Telephone numbers were "state secrets" merely a few years ago.

2. I want to avoid the prejudicial connotation of the word that some Americans so condescendingly use (and many Chinese so justifiably hate) to describe the Chinese people.

3. In China, judges, lawyers, and other legal personnel are called collectively "legal workers." 


\section{A. The Vertical Strata}

In both the legal and trade professions, there are four distinctive age groups: the seniors or "veterans," the juniors or "midstreamers," the sophomores or "WPS" (Worker-Peasant-Soldiers), and the freshmen or "newcomers." Because of the socialist seniority system, the traditional Chinese respect for age, and, even more importantly, the distinctive political atmosphere of each of the People's Republic of China's ("PRC") historical stages, it is important to examine the ideological and social background of each group before we conduct an analytical study of their respective behavioral patterns.

1. The Veterans/Seniors. These people have been in the legal and trade professions since at least the 1950's. A few of them worked as businessmen for the communist armies ${ }^{4}$ before the founding of the PRC in 1949. Some worked for foreign or Chinese private firms (mostly trading companies) or colleges under the old regime and were "co-opted" by the new government. But the majority of this group was trained directly by the People's Government after 1949. The legal education received by this group from the early 1950's until the Anti-Rightist Movement in $1957^{5}$ was substantial and strongly influenced by the Soviet system.

The lawyers and trade personnel trained during this period can be represented by graduates of Chinese People's University (Renda); its curriculum also epitomized law school curricula of that time. Located in Beijing, the People's University was established by the government right after the 1949 Revolution as the key higher educational institution for the Party and government cadres. The law faculty, then considered the best in China, comprised a potpourri of the best teaching staff from distinguished preLiberation law schools, ${ }^{6}$ communist base area universities, ${ }^{7}$ and Soviet universities. $^{8}$

4. These included the Red Army of the first civil war period (1927-1937), the Eighth Route Army of the Anti-Japanese War and second civil war period (1937-1948), and the People's Liberation Army of the last years of the struggle against the Nationalists and of the period since the establishment of the People's Republic of China ("PRC") in 1949.

5. The Anti-Rightist Movement began in June 1957 when Mao Zedong abruptly ended the Hundred Flowers Movement. This latter term is derived from Mao's famous quotation: "Let a hundred flowers blossom and a hundred schools of thought contend." Those intellectuals who took the Great Chairman's words seriously and voiced criticisms of the Communist Party found themselves labelled rightists and "poisonous weeds" and suffered for the next twenty years. The "Howers," of course, all withered in just a few months.

6. Peking (Beijing) University, Qinghua University, Zhongguo (China) University, and the Zhaoyang Law School all contributed faculty. Zhaoyang supplied a substantial number of judges and other legal personnel for the pre-Liberation court system-hence the saying "It isn't a court if there's no one from Zhaoyang (wuzhao buchengyuan)." Many of these people formed the Beijing Institute of Politics and Law, which a few years later merged with several other schools to form People's University (Renda).

7. These included, for example, Huabei (North China) University, Yan'an (Yenan) University, and the Anti-Japanese Military and Politics University.

8. There were at any time during the first few years of this period over a hundred Soviet professors in the university, and most of them were professors of law, foreign trade, or economics. 
Since it is an excellent representation of the legal and political education in China at that time, the curriculum of the People's University should be examined in order to understand the ideological formation and legal background of the senior cadres.

a. Theories of the state and the law. This course was basically a MarxistLeninist analysis of the emergence, development, functioning, and eventual withering away of the state, and of the law as a superstructure serving its economic foundations. This course has always been compulsory and has remained one of the most important courses throughout the history of legal education in the PRC. This explains why before any new law is promulgated, there is always a tremendous amount of effort devoted to defining its theoretical/ideological basis. ${ }^{9}$ For example, before the enactment of the PRC Patent Law, the theoretical basis of the concept "patent" had to be harmonized with the Marxist concept of the "means of production." The delay in passing the much-revised Civil Code, ${ }^{10}$ which derives a substantial amount of its theoretical basis from Marxism-Leninism rather than from the Napoleonic Code, is probably a result of political questions. These concerns for correct ideological foundations also explain, more importantly, why China is not taking a "capitalist road" as hoped for and believed by many in the West, and why it probably never will. This theoretical basis is almost an insurmountable wall confronting any present Chinese communist leader who might try to take a capitalist road. ${ }^{11}$ The effect of this "wall" on Chinese legal thinking will be discussed later in this article.

b. Constitutional law. Before 1954, the Soviet Constitution and the constitutions of the Eastern European countries were the main teaching materials. ${ }^{12}$ After the first Constitution of the PRC was promulgated in 1954, the Chinese Constitution, which incorporated some characteristic Chinese legal concepts, was added to this course. Foreigners sometimes find it odd that this document and all subsequent versions comprise articles which provide that "citizens of the PRC have the right ... to work, ... to rest, [and]

9. When we talk about "theoretical basis" in China, we mean the theories of Marx, Engels, Lenin, Stalin, and Mao.

10. In fact, when the Civil Code finally came out in its present form after much compromise among different opinion groups, the code became so abridged that it no longer justified the name "civil code"-hence the title General Principles of the Civil Law.

11. On the much-reported hoopla about China"s "discarding" or "outdating" MarxismLeninism, see, e.g., the February 8, 1985, New York Times and Washington Post articles regarding an editorial carried in the February 7, 1985, People's Daily. The editorial discussed the application of Marxism-Leninism to the Chinese situation-something Chinese leaders had been talking about for the past fifty years. In the February 14, 1985, People's Daily, the Chinese Communist Party responded with a statement that is another piece of evidence that China will not discard Marxism-at least not in the foreseeable future.

12. A distinction was made between the Soviet Union and the Eastern European countries. The former was considered a socialist country, hence more closely resembling the communist models envisioned by Marx, Engels, and Lenin. The latter were the "People's Democratic Countries," which connoted a lower stage on the path of development toward a communist society. This distinction was reflected in the two types of constitutions. 
... receive an education."'13 To the majority of the people in China, however, those were very substantial rights and were at least as important as the United States' constitutional protection of freedom of speech. The pre-Liberation experience of many Chinese people had made the guarantee of these rights one of the most important goals to achieve in their struggle against the old regime. To them, these rights were every bit as "fundamental" as one's right to live, and were hard-won fruits of the revolution, not to be easily relinquished. Up until the Cultural Revolution, therefore, the Chinese equivalent of "constitutionalism" had occupied the forefront of the legal debates. Although this "entitlement" did not pose much of a problem in the 1950's, it later became an important reason for the continued difficulty not only in firing incompetent workers, but also in removing the supernumeraries from the negotiating table and the decisionmaking process, both domestically and in many of the transactions with foreigners.

c. Criminal law (including criminal procedure, criminal investigation, forensic psychiatry, and forensic medicine). Although these courses were likewise heavily influenced by the Soviet system, there were some distinctive Chinese elements in them. One of the most obvious differences between the two systems is that Soviet criminal procedure emphasized the check and balance of the separate vertical leadership of each legal instrumentality, while the Chinese system stressed horizontal coordination and cooperation among the different units, namely, the police, the prosecution, and the court. This Chinese concept of criminal justice may lead to abuse of power since there may not be enough checks and balances among the various branches of the state machine. What actually happened, however, proved that the majority of the population favored substantial and swift justice over doctrinal and technically "neat" procedures. ${ }^{14}$ This attitude has contributed much to the general acquiescence or ambivalence towards the kind of "simpler procedures" (jianyi chengxu) used in many capital punishment cases. ${ }^{15}$

d. Civil law and civil procedure. The Soviet Civil Code and its procedures were covered in detail. Although both the Soviet and the Chinese civil laws were, at least indirectly, based on the French and German systems, there were some substantial differences that largely reflected Marxist-Leninist concepts of property rights, obligations, and the relationship between persons and various economic entities. Since private ownership of the means of

13. See, e.g., articles 42, 43, and 46 of the Constitution of the People's Republic of China (1982).

14. This again reflects age-old Chinese mentality that is deeply rooted in the culture. Cf. note 58 infra and its preceding text. What happened later during the various political movements, especially during the Cultural Revolution, however, was not exactly the kind of abuse of power the check and balance concept was designed to prevent. When an entire legal system is rendered impotent in the face of the will of the Party or of one man, it becomes a totally chaotic situation of no law at all. That is the so-called "masses' dictatorship" much favored by the Gang of Four.

15. See, e.g., Accelerated Trial Procedures for Criminal Elements Who Seriously Damage the Social Order. Renmin ribao (People's Daily), September 3, 1983, at 3, and Supplementary Rules Concerning Time Limits for Handling Criminal Cases, People's Daily. July 8, 1984, at 4, both of which were established to deal with urban street crime by facilitating swift and harsh (including capital) punishment. 
production (shengchan ziliao) is theoretically abolished in a socialist country, the part of the civil law and subordinate laws that dealt with, among other things, contracts, corporations, commercial paper, maritime transactions, insurance, and securities transactions was either vitiated or expunged. Private ownership of personal property and non-productive real property (shenghuo ziliao) was recognized as a transitional phenomenon under the socialist system. Therefore, the part of civil law dealing with inheritance of shenghuo ziliao was retained. Tort law had to exist as long as there were personal injuries. ${ }^{16}$ Copyright and the right to inventions, which are similar to patent rights, were still recognized, but in a limited way. ${ }^{17}$

e. Marriage law. Marriage law was probably the only major course that did not derive too much from the Soviet system because one had been developed in the Jiangxi Soviet ${ }^{18}$ and because the Chinese conditions that prompted its emergence were so distinct from the Soviet experience. However, since this area of law is not germane to the present topic, it will not be explored further.

f. International public law. This course was also heavily influenced by the Soviets. Some Soviet legal theories which developed over the years after the 1917 Revolution show important differences from their European counterparts. As one can imagine, however, this is not the kind of law that can be tailored or manipulated to suit the taste of any given country. Therefore, it was still taught with materials similar to those used in the preLiberation days when mostly civil law tradition was adopted.

g. International private law. This course had attributes similar to the public law course. However, because of the success of the United States-led embargo in isolating China from much of the rest of the world (other than the Eastern Bloc countries), private law issues, even those dealing with potentially problematic areas such as foreign trade contracts and Sino-foreign marriage and inheritance, were more theoretical than practical. The theories developed by Soviet scholars concerning the relationship of a revolutionary regime towards its overthrown predecessor also supplied ammunition to the Chinese Government in her rejection of the claims against certain loan obligations incurred by the previous government. ${ }^{19}$

16. The necessity for retaining some form of tort law, however, gradually diminished with the communization of the economy-hence the creation of a national labor protection and compensation system.

17. See, e.g., Regulations on Rewards and Encouragement of Inventions (1963), Regulations on Reward and Encouragement of Technological Improvements (1963), and Regulations on Rewards and Encouragement of Inventions of the People's Republic of China (1976).

18. "Jiangxi Soviet" is the name of the early Chinese revolutionary government established by the Communists in southern Jiangxi province in 1931. It lasted until the Nationalists forced the Communists from the region in 1934 .

19. Theroux \& Peele, China and Sovereign Immunity: The Huguang Railuay Bond Case, 2 CHina L. REP. 129-52 (1982). See also Sgro, China's Stance on Sovereign Immunity. A Critical Perspective on C.S. 
h. Legal writing. Form has never reached the degree of importance in the Chinese legal system that it has in the common law system. What was prepared by the courts and taught in schools was only for the purpose of judicial expedience. This became more true under the Communist Government, one of whose avowed goals was to destroy the old, overelaborate, and red-tape-ridden "bourgeois legal system" that protected only the landlord and the capitalist class and exploited the poor. This explains why most, if not all, Chinese law students are often perplexed by the kind of "battle of forms" that goes on all the time in U.S. courts.

There were some other law courses of lesser (at least for the purposes of this article) importance, such as legal accounting, labor law, and the law of collective farms, most of which follow the same pattern of Chinese modification of Soviet models. Apart from these law courses, some general courses were also required, including Chinese language, political economy, foreign languages (Russian for most of the 1950's), and above all, the "four great theoretical courses." This is a term that has been used throughout the post-Liberation years for the four different subjects of Marxist-Leninist theory-that is, philosophy, political economy, the history of the Chinese Communist Party, and the basics of Marxism which included the history of the Soviet Communist Party in the 1950's and later the history of the international communist movement. With condensed versions for students of science and technology and more demanding requirements for those in the social sciences, these courses have been required of all college students in China since the early 1950's. The centrality of these courses explains why the "Left" keeps coming back despite the inherent pragmatism of the Chinese people.

Like law students, those from the Foreign Trade Department of People's University ${ }^{20}$ had a substantial education in the "four great theories" and took many courses from Soviet experts. Since Marxist economic theory was already quite complete, as compared to the piecemeal form of the legal theories, these students could be said to be better equipped in terms of theory.

Lenin had envisioned a state-monopolized foreign trade system and had implemented one in the newly established Soviet Republic. This system was based not merely on practical considerations; it also had a theoretical basis in the overall Marxist socialist theory of:

(1) the inevitable establishment of a planned economy in a socialized modern production system that calls for the public ownership of all the production means;

Practices, 22 Colum. J. Transnat'l L. 101-34 (1983), and Wang Houli, Sovereign Immunity: Chinese Views and Practices, 1 J. Chinese L. 23 (1987).

20. In the 1950's, this department became the Beijing Institute of Foreign Trade ("BIFT"'), which until the early 1980's was the only institution of higher education in China for training foreign trade personnel. In 1983 it became the University of International Business and Economics ("UIBE"). 
(2) the necessity of the planned economy to stay alive in a hostile environment, that is, not to be stifled when making its efforts to build the New Society by competition from the "monopolized capital" of the more economically advanced countries; and

(3) the need to speed up the modernization process by absorbing advanced technology created by other nations (including, of course, capitalist ones), and by utilizing international capital to finance the socialist economy.

In a nutshell, a state monopoly over foreign trade was essential to, in Lenin's words, "protect the cradle of world socialism, and to dig the grave for world capitalism."

Having discussed the theories taught to and firmly believed in by many of these veterans, we can now turn to the political tone of that time and its impact on the thinking process of these people.

In the first four to five years of the 1950's, the Revolution's early days, the whole state machinery was strictly egalitarian and basically militarized. ${ }^{21}$ The whole machine was young, making it possible for self-sacrifice and altruism to take root. Legal staff, foreign trade personnel, and the students from colleges and universities such as People's University wore uniforms, ate from "a big pot" (equal quantity for each individual), and expected no pay except some very meager pocket money (jintie). Working for oneself, not to mention making a "profit" for oneself, was shameful. After all, it was the early days of a great revolution; people were filled with enthusiasm and inspiration. To them, the old state machine was rotten to the core. Hence, the superstructure of that system, of which the legal system was a part, had to be smashed in toto. They believed that atrophying industrialized countries would also be smashed sooner or later. The only new society that stood out as worthy of emulation was the Soviet Union, which, to the new revolutionaries, shone from the horizon like a rising sun.

Just a few months after the founding of the People's Republic, the "great savior" himself, Chairman Mao, went to the Soviet Union, the only foreign country he would ever visit. A Treaty of Friendly Commerce and Navigation was signed by Mao and Stalin. Machines, equipment, all kinds of manufactured goods, and thousands of experts poured into China. Flowing in the opposite direction, thousands of Chinese officials, students, and workers were sent to the Soviet Union to gain useful knowledge and experience from their "big brother." Anything later said about the discord between the two giants during that meeting was certainly not conveyed to the general public and hence had no influence on the people who were led to side with the Soviet Union without much reservation. ${ }^{22}$ This lopsided situation

21. Differential economic treatment according to rank, which is inherent in a military institution, was almost nonexistent. Everyone-from the commander of an army to the cook in a platoon-got basically the same pay. This is what we call "military communism."

22. "We surely must lean to one side," said Mao in his famous critique of the later-rehabilitated "Hu Feng Anti-Party Clique" in the early 1950's. Mao was responding to criticism that China was 
was substantially aggravated by the United States-led embargo following the escalation of the Korean War, which is still referred to in China today as the "Resist-America-and-Assist-Korea-War" (kangmei yuanchao zhanzheng).

During the war, the internal Land Reform and the Agricultural Cooperation Movement were being implemented. To ensure the successes of these policies and solidify the newly established government in the face of the American threat, a purge (called Zhen-fan, the Movement to Suppress the Counter-revolutionaries) was initiated. Many people in law and foreign trade from the old regime were required to leave their posts; only those of "good class background" and/or clear ideological consciousness, that is, firm belief in Marxism-Leninism, were retained. This process affected college students as well. The events that followed only strengthened people's beliefs in the correctness and, ironically, the safeness of following the Party line; for in 1957 the Anti-Rightist Movement led to the banishment of many judges, scholars, businessmen, and "legal workers" from the professions.

The Great Leap Forward of 1958 fueled the so-called "law-nihilism" that had appeared in the previous year and eventually resulted in the great simplification, or rather, dismantling of the whole legal system. The three branches of law enforcement-the Public Security Bureau (gong), the Procuratorate (jian), and the People's Court $(f a)$, were now unified in one office (he shu bangong). Study of law was reduced to a single course (yitiaolong), the "People's Politics and Law," which had criminal law and procedure as its major components but included civil procedure and marriage law. Before long, hard economic reality halted the Great Leap, but the effect of the movement echoed long after the frenzy was over.

To sum up, because of their formal education and political experiences, these veterans are the most orthodox, cautious, and idealistic types. Since most of them are holding some kind of responsible position, their influence in the professions cannot be overestimated. ${ }^{23}$

2. The Midstream/Juniors. After the "three-year natural disaster period" (the official Chinese term for the disastrous post-Leap famine-stricken years of 1959-61) was over, the mentality of the rank and file changed sharply. This was the result not only of the disillusioning economic failure, but also, and perhaps more importantly, of the publicizing of the cleavages between the Communist Party of China and the Soviet Communist Party. The rupture between the two Parties, together with the two Anti-Rightist Movements in 1957 and 1959, had such an impact on legal education and all other areas of

\footnotetext{
leaning too much towards the Soviet Union. On the campaign against Hu Feng, see M. MEISNER, MaO's China 134-35 (1986).

23. The majority of the national level managerial and administrative positions are at the present time occupied by the seniors.
} 
social sciences that college graduates of $1960-66^{24}$ should be seen as a group distinct from those of the 1950's.

During this period, a dichotomous trend appeared in the educational system. On the one hand, it freed itself from the "Soviet revisionist" -style education of the 1950's and created a new Chinese educational system which adapted Marxism-Leninism to the particular Chinese legal, economic, and foreign trade theories. On the other hand, it strengthened its adherence to the Chinese Communist Party line and hence discouraged criticism and open deviation. The changes were especially obvious in legal education where all the Soviet law courses were cancelled (most of the Soviet professors had left in the mid-1950's). When comparative studies were necessary, Western legal systems were the standards. The Soviet laws were hardly even mentioned, since it would be hard for the professor to differentiate them politically from the Chinese laws. However, other than this "de-Sovietization" the basic legal curriculum remained almost as comprehensive as in the early 1950's.

In the foreign trade area, the change in theories was less discernible. The basic economic theories did not change because the Chinese were represented as the true Marxist/Leninists as opposed to the Soviet "revisionists." Neither did the foreign trade theories change, since China was to remain a "real" socialist country. In practice, however, foreign trade underwent drastic changes in the early 1960's. Khrushchev, then Soviet Party Chairman and Premier, ordered all contracts between the two countries cancelled and all experts withdrawn. Trade between China and all Eastern Bloc countries was reduced to a trickle. These events made it necessary for China to seek other trade channels. Internationally adopted trade procedures and practices once again became important. Trade terms and definitions were no longer academic questions but of more practical importance. A differentiating trade policy ${ }^{25}$ became necessary, too, because of the dazzling changes in the traditional patterns of friendship and hostility. After all, China was a socialist country and had legitimate reasons to be concerned with whom it was dealing, and whether to treat the particular party "fairly," "generously," or selflessly."

These paradoxical developments in legal and trade education were perhaps due to the environments of the two fields: Legal personnel were to function mainly internally. Hence, they were more concerned with the traditional approaches of managing Chinese society and did not have to encounter an extant and self-perpetuating system, as did the trade people. The trade people, on the other hand, did not have an urgent need to change their theories so long as the "means" served the "ends." This divergence deepened over the years and actually has lasted to the present time.

24. The classes of 1967 to 1970 are also included in this group for reasons to be discussed later (in note 28 and its accompanying text), although their educations were significantly disrupted by the Cultural Revolution.

25. UIBE teaches a small course on this topic, one of which there is little knowledge and in which there is little interest outside foreign trade circles. 
The prior hardships of both the seniors and juniors paled in the face of the Cultural Revolution, which was in a sense a rational continuation and logical outcome of Chairman Mao's previous policies. ${ }^{26}$ After all, schools were closed; there were no more curricula to talk about. ${ }^{27}$ However, I classify the "Red Guard College Students" as belonging to the same group as other juniors because they were already in colleges and were influenced by the more academic atmosphere of the higher education institutions. ${ }^{28}$ They were more apt to reason out and contemplate events than were the students in middle and primary schools who would later form the next category: the WPS students.

Foreign trade never totally stopped. The Canton Trade Fair ${ }^{29}$ was still held twice a year, attracting businessmen from all over the world with the prospect of making some quick profits. ${ }^{30}$ The typical attitude of a foreign trade "worker" was that "business is still business," despite the fact that there were orders to obey, policies to follow, and new things to adjust to.

The legal personnel, on the other hand, had an experience few would envy. Since it was a "revolution," the "old" judicial system was no longer useful. Jiang Qing"31 called for "smashing the reactionary gong-jian-fa [that is, the public security, the procuratorate, and the courts] into pieces." This organ was indeed literally smashed, as were many of the people therein. People possessing legal knowledge were either too dangerous to the Revolution or too useless to be allowed to remain in the urban centers. That was because, in Jiang Qing's words, "the [ever-changing] order of the Revolution is the best order," and lawyers/legal workers would only disrupt this revolutionary order with their knowledge of the older order. They became, therefore, the first groups of subjects to be sent to the rural areas to receive re-education from the peasants. The only law was the word of Chairman Mao and a few others. Even that "law" later became ineffective, since, as a traditional Chinese saying goes, "the sky is high and the emperor is far away." In such anarchy, the knowledge of some old law was considered "less worthy than a dog's fart."

26. There were many changes in theory during that period, but they were all along the line of what is now called the "extreme leftist line," albeit with varying degrees of aggravation or alleviation.

27. College enrollment halted by the summer of 1966 . Normal classes in most colleges were stopped in the fall of 1965. By the summer of 1966, all colleges, high schools, junior high schools, and elementary schools were closed. A few colleges re-opened their doors in the early 1970's, but most others did not do so until the mid- or late 1970's.

28. Hongweibing daxuesheng (Red Guard university students)-the classes of 1967-1970 who were enrolled before the Cultural Revolution-started but never had the chance to finish their schooling and were instead thrown into the Cultural Revolution, as opposed to the lao daxuesheng, the "old college students," who graduated before the fall of 1966 .

29. It is officially called the "China Guangdong Import and Export Commodities Fair."

30. An anecdote: A dancing stage was set up in front of the Trade Fair in 1967 for the purpose of inviting foreign friends to join the "Loyalty Dance." Holding Mao's Little Red Book as they tried to please their hosts (or, more accurately, patrons), scores of Western and Japanese businessmen jumped on the stage and started a real circus of twist and swim dances to the tune of "Our Beloved Chairman Mao" and "The Great Helmsman."

31. Jiang Qing was a leader of the left during the Cultural Revolution and one of the notorious Gang of Four who were blamed for the movement itself and most of its excesses. 
Still, despite their varying experiences, as a group the "midstream/juniors" have some common attributes. They are on the whole very mature, proficient (both politically and professionally), and relatively flexible. Politically, they are familiar with the more orthodox communist theories, yet they do not adopt the Soviet way of administering the economy or justice or trade. They know the new trends in the world, but they do not adopt radical lines. Professionally, they have a good grasp of academic knowledge ${ }^{32}$ and solid experience through many years of working at the grass-roots level. More importantly, they are generally accepted by their seniors for their maturity, and at the same time by their juniors for their flexibility. Many of them, therefore, are now well on their way to positions of power.

3. The WPS/Sophomores. "WPS" is the short form for the so-called "Worker-Peasant-Soldier" students. This is a special group in the history of the PRC and, in a sense, an anomaly. Considered the direct product of the Cultural Revolution, this group underwent considerable psychological upheaval during and immediately after their school days, perhaps more so than any of the other groups being discussed here.

In the heyday of the Cultural Revolution, all students were used to carrying out political tasks. When the immediate objective of disgracing and ousting Chairman Mao's political enemies was achieved, the need for people of higher learning (in certain areas at least) became apparent to Chairman Mao himself. So, five years after the closing of all the higher educational institutions, there came a piece of "His Supreme Instructions" (zuigao zhishi): "Universities are still necessary. I mean mainly those of science and technology. ..."33

The national examination system was not revived, since "political quality" was the first concern. A recommendation system was adopted instead. With recommendations from fellow workers, peasants, or soldiers, a candidate with two years of prior working experience could pass the first stage. Then, a check of family background was made to insure good class standing. ${ }^{34}$ The leaders of each unit, the factory, the commune, or the army unit (usually at the regiment level), recommended candidates for admission to college.

Final decisions, however, depended on the quota system by which the State Planning Committee distributed the number of positions in each university to the various provinces, and the Provincial Planning Committee ${ }^{35}$ in turn distributed them to the various factories and communes. The People's

32. With the possible exception of some Red Guard students, they are strong academically.

33. That was the term used during the Cultural Revolution for Chairman Mao's directives and sayings.

34. This meant that the candidate's parents should not have been from families of landlords, rich peasants, capitalists, counter-revolutionaries, or officials of the old regime. "Rightists" or "bad elements" were also included in this outcast category. In fact, anyone who was not economically poor before 1949, or anyone who was convicted or even suspected of opposing the new regime, would make all their close relatives presumptively ineligible.

35. During most of the Cultural Revolution period, this was the Production Group or the Education Group of the Provincial Revolutionary Committee. 
Liberation Army ("PLA") had an independent system, receiving a quota directly from the State Planning Committee. No one could go to a college unless he/she was "recommended" and unless his/her unit had obtained a quota. Since the successful candidates had worked in units for at least two years, and were thus bona fide workers, peasants, or soldiers, they were called the "WPS students" ("WPS").

This peculiar enrollment system resulted in many problems, the most serious of which was the academic performance of the students. Although the curricula were greatly simplified, many students who had hardly finished the sixth grade had tremendous problems in their efforts to become "both red and expert," that is, to follow Chairman Mao's instruction to become both politically and academically proficient. On the other hand, a few WPS found it easy to digest the so-called "university level" knowledge and started seeking satisfaction elsewhere, in particular in politically unorthodox theories for the revolution, and in scheming against each other.

Because a large number of WPS are poorly prepared academically and intellectually, people tend to deprecate this whole group as lower caliber. This somewhat slanted view was aggravated by the fact that many WPS were much more "worldly" than traditional college graduates due to their working and political experiences, and thus were able to climb the political ladder faster than others. Since the number of WPS is not insubstantial, they are a force in the professions that cannot be ignored. A major consideration in understanding the WPS group is that their competency varies widely. One person may have enough practical experience to overcome the handicaps of his/her background; another is overwhelmed by the demands of his/her profession.

4. The New Graduates/Freshmen. The term "new graduates" refers to those who entered college after the Cultural Revolution ended in 1976. This group is distinct from the other groups not only in terms of age and experience but also in terms of education and world outlook.

Because of the Cultural Revolution, many in this group suffered hardships when they were too young to be conscious of their problems. When they began to be more critical of their surroundings, material conditions had improved. Ideologically, however, the whole nation became much less uniform towards the end of the Cultural Revolution. It was at this time that people who are now new graduates heard a lot about the unstable political situation and many complaints about corruption. ${ }^{36}$ They, unlike their WPS predecessors, had to take a very competitive national college entrance examination which only 4-6 percent of high school graduates passed each year. ${ }^{37}$ Therefore, many of them, also in contrast to their predecessors, do

36. One especially disillusioning phenomenon was that many of the "revolutionary rebels" who got into power by "making proletarian revolution" soon took advantage of their positions for personal political and economic gain.

37. This reflected not only the quality of high school education but also the lack of higher educational facilities. 
not share a feeling of gratitude or appreciation towards "the Party and the people." 38 This is because many of them feel that their chance to go to college was earned through their own hard work and intelligence rather than their political background or connections. Their arrival in college coincided with the beginning of the so-called "open-door policy" when all sorts of "new ideas" surged in, filling their heads with openly unorothodox thoughts, diametrically contradicting theories, seemingly appealing political propositions, and various unconventional "cultural novelties." This period's curricula were an experimental matter as the desire of some veteran professors to go back to the "good old days" of the 1950's clashed with the attempt of others, many of them younger "veterans," to bring pragmatism into the system.

One telling feature of a typical law curriculum nowadays is its inclusion of a course on what has come to be known as "foreign economic law." This course typically consists of condensed descriptions of both the Continental and the Anglo-American laws of contracts, commercial paper, corporations and other business associations, and certain areas of torts such as product liability and admiralty. In short, any foreign law that has a substantial bearing on China's economic relations with foreign parties is supposed to be included in the course. A few law schools have started to further expand this concept so as to open full-featured courses on foreign contracts, corporations, and admiralty. Some traditional courses of international law are also expanded to serve the more economically oriented reality. And many law schools hold symposia and lectures on foreign and international laws, often with participation by foreign professors and lawyers.

Improvement of the curriculum in business schools like the one under the University of International Business and Economics ("UIBE") is more a matter of replenishment than of renovation. Courses on foreign laws, Western economic theories, business organizations, marketing techniques, and trade statistics are among those which have been substantially supplemented. Schooling has been extended to five years (as compared to three and a half years for the WPS) and more extensive study of foreign languages and other supplementary subjects is required.

The student body is considerably different, too. The new students are not only much younger than their WPS and, to a certain extent, veteran predecessors, since almost all of them come directly from high schools; 39 but they are also different from all of the previous groups in the sense that a great majority of them are either the only child or one of two children in a family, as

38. This cliche has been used time and again in the PRC's history to refer to the source of the mandate given to the college students. It has been used less often in the past decade by college students because many of the new graduates feel that their chance to go to college was earned on the basis of hard work and ability rather than bestowed on the basis of political background or connections.

39. One exception is the 1977 class, which absorbed many talented youngsters who had been kept out of college for many years by the so-called "recommendation system" and the stringent political background requirements. 
compared to their predecessors' more traditional multi-sibling families. This, of course, means a much easier life and better education for them. In this respect, they are more like their American counterparts than their Chinese predecessors.

None of what has been said above concerning the new graduates, however, should be taken as a statement that the overall political tone of China's legal education is substantially different. Contrary to an untrained Westerner's impressions, and perhaps also to his wishful thinking, the inculcation of Marxist-Leninist ideology as reflected in the so-called "four great theoretical courses" is still one of the most important goals to be achieved in legal education. The efforts to achieve this goal, of course, meet with many countervailing forces, not only from the inquisitive youthful minds of the students, but also from the drifting, suspicious, and confused attitudes of many teachers of these very courses. Nonetheless, ideological work and political propaganda are emphasized over and over by the Party Central Committee as an important part of college education. ${ }^{40}$ Moreover, the Communist Party has been making a major effort to recruit new members from among the college professors and students, an effort unprecedented in the Party's post-Liberation history since intellectuals had always been considered part of the "bourgeois class" and hence not prone to revolution. Perhaps that is why, contrary to the proclamation of the Party's new antidiscrimination policy, it is still routine to have the enrollee's background checked to insure the potential graduate's subscription to the Party line.

The number of people from this freshman group is, of course, increasing yearly and foreigners are likely to encounter them more often in the future. They are, therefore, a potentially important group in the professions in question. So far, however, they are still considered too young and inexperienced to play a significant role in the decisionmaking process.

\section{B. Horizontal Categorization}

People from both the legal and the trade professions are divided according to the colleges from which they graduate and the geographical regions in which they work. For the purposes of this article, the discussion is limited to the different categories of schools and the four sources from which foreign trade personnel come today.

1. Regular Business Schools. Regular business schools consist of the University of International Business and Economics ("UIBE"), formerly the Beijing Institute of Foreign Trade ("BIFT"), and its recent "spinoffs": the Shanghai Institute of Foreign Trade ("SIFT"), the Guangzhou Institute of Foreign Trade ("GIFT"), and the Tianjin Institute of Foreign Trade (“TIFT").

40. Following the nationwide student unrest in the winter of 1986-1987, the Party's Central Committee renewed attention to ideological work among college students. 
This group of schools is under the direct leadership of the Ministry of Foreign Economic Relations \& Trade ("MOFERT") and is responsible for the training of personnel for MOFERT and the various foreign trade corporations ("FTC's") directly affiliated with MOFERT.41 As discussed earlier, graduates from these schools are generally better equipped theoretically and are therefore more inclined to accept Lenin's theory of a state-monopolized foreign trade system.

2. Local Foreign Trade Schools. This group includes all the foreign trade schools at the provincial level. There are now about twenty of them and the number is increasing. The main task of these schools is to train personnel for the Foreign Trade Bureaus of their respective provinces and their affiliated local FTC's. The quality of these schools varies considerably, depending mainly on their locations-more specifically, the relative importance of foreign trade in their respective provinces. Length of schooling varies, too. In most cases, the length of schooling is two years, while a few more advanced schools require three years to graduate. Traditionally, these schools accepted junior high school graduates, but in recent years some have switched to accepting only senior high graduates. The reason for this change is the greater abundance of these better qualified students. Since members of this group tend to have strong ties to their particular locality, they play an important role in the ever present competition between the central and local governments.

3. Cadre Training Classes. These classes were begun mainly to alleviate the acute shortage of foreign trade personnel in the early stage of the "open-door policy." Many of the students were ex-soldiers with rarely more than a junior high or elementary school education. It is therefore not surprising to find many in this group still incompetent, even after the half-year to one-year training session. These sessions consist of cram courses similar in content and structure to the yitiaolong courses, but without supplementary theoretical studies. With the on-job examination system being adopted in many units, these people are being forced either to try to upgrade themselves through self-education or to leave the job for something more commensurate with their skills.

4. Foreign Language Students. This is another approach taken by the State Planning Commission in the past decade to remedy the shortage of hands in the nation's quickly expanding foreign trade. Graduates from the Beijing Institute of Foreign Languages, now the University of Foreign Literature and Languages, and from the English departments of Peking University (Beida)

41. This includes not only the central FTC's but also the few "General Corporations" at the provincial and municipal level as specially approved by the central government. Certain other general corporations have been established outside of MOFERT in recent years. These corporations have not been very successful in recruiting from the MOFERT schools because they are all controlled by other central ministries and threaten to compete with MOFERT. 
and other universities were assigned to work in the foreign trade field rather than their traditional fields of general foreign affairs, foreign language teaching, and foreign literature. Although their college education by and large did not prepare them for their new jobs, these people are generally quite adaptable, probably because of their high educational levels and experience with foreign languages. However, this affects their "theoretical basis" 42 in the field, as well as their chances of advancing themselves in their professions.

\section{Law-Trained Personnel. Legal personnel come mainly from three} sources.

a. Regular law schools. This category comprises the law faculties and departments in the major national and provincial universities and the one university (China University of Politics and Law) and three Institutes of Law and Politics (zhengfa xueyuan) of East China (in Shanghai), Northwest China (in Xian), and Southwest China (in Chengdu). This group of schools represents the general direction of higher legal education in present-day China. Owing to the highly political nature of these schools, as reflected in their curricula, and the kind of work to which their graduates are generally assigned, these people, in comparison with the trade personnel, may be more orthodox in ideology and less flexible in terms of foreign dealings.

b. Cadre training classes. This mechanism is similar to the one mentioned above in the foreign trade section, both in terms of its schooling and of its function. Students of these classes are, besides the demobilized soldiers described below, old cadres who were assigned to work in this field in the past, not because of their specialty but simply because of the need to have someone, anyone, do the work. These "street activists," as they are respectfully called, frequently play the roles of local mediators and sometimes the "people's assessors." 43

c. Ex-soldiers. This group is also trained in the cadre training classes. The reason for distinguishing them is that there are a very large number of them at the grass-roots level and their specific background and mentality justify some special consideration. Since military service starts at the age of eighteen, none of these ex-soldiers has had higher education before being assigned to work in the profession. The strict military training and intensive ideological work form an important part of their background which inevitably affects their way of thinking and behavior.

42. Cf. supra note 9 and accompanying text.

43. The "people's assessors" system in China is fundamentally different from the American jury system in that the assessors are specifically and permanently designated and approved by the court, are permitted (and indeed expected) to consider all the pieces of evidence, including the public's opinion, that come to the court, and are trained in law. They are, in a sense, more like quasi-judges. Indeed, the two systems sound alike only in their names-the Chinese translation for "juror" being the same as the Chinese term for "people's assessor." 
Many of the cadre-class trainees go back to classrooms (which is usually referred to as "being re-baked in the oven" (huilu)) to receive more advanced education or to solidify what they have learned before either through classes or experience.

d. Foreign educated. There is another group which may be worthy of mentioning here: those who have studied law or business in the West, especially in the U.S. Although the total number is very small-a few hundred in business trade and about a hundred in law-the quality of this group is on the average much higher. They may, therefore, have some impact in their professions respectively and jointly, and may stand a better chance of getting into the rank of the policy formulators and decisionmakers. This, however, is dependent on the overall political environment in China in the next decade or so. ${ }^{44}$

III

\section{People Behind the Scenes}

The groups of people discussed above, vertically and horizontally, are those whom foreign lawyers and businessman are likely to encounter directly. Then, there are those who are not ordinarily available for face-to-face negotiations but who, nonetheless, have a lot of say: the "bosses." Remember, of course, a purely arbitrary command by any single person is highly unlikely nowadays; and it is in fact more difficult for a Chinese "boss" to order anything to be done than it is for his American counterpart. These people come increasingly from the above-mentioned groups, mainly because of seniority. There are (more in the legal profession than in trade) still some real veterans, more "veteran" than the seniors.

These people typically joined the Revolution in the 1930's or 1940's and can be divided into three categories according to their backgrounds.

In the first category are veterans from Yan'an (Yenan). During the 1942 embargo by the Japanese and the Nationalist armies against the Red Base Area, the need to survive prompted the Party to create "Red Merchants," who would discreetly conduct business transactions between the Red Area and the White Area.45 By the same token, "Red Judges" were also created for the administration of justice in the Red Area when Communist control became much more stable after the mid-1930's.

The second category is made up of veterans from the same era who were later trained in the Soviet Union. These people have a very solid grasp of

44. The Party Congress in the fall of 1987 showed the strength of another contingent of foreigneducated technocrats - those graduates of Soviet and other Eastern European universities who came back to China in the late 1950's and early 1960's. Among the most prominent were Li Peng, then Vice-Premier of the State Council, Song Jian, the chairman of the State Science and Technology Commission, and several other ministerial level cadres.

45. The terms "Red Area" and "White Area" were used by the Communists before 1949 to identify those areas occupied, respectively, by themselves and by their enemies, the Nationalists. The Nationalists called the Communists "bandits" and the Communist-occupied regions "bandit areas." 
Marxist-Leninist theories and tend to be the most orthodox of all the people under consideration in this article.

The third category includes those who were educated in Europe or the United States, many of whom joined the Chinese Communist Party ("CPC") or even the American Communist Party during their school days in the "capitalist dens." This group is not large, and for a long time most of them lived a quite precarious life because of their backgrounds and, in some cases, their political views, which had a tint of "bourgeois thinking." However, since Deng Xiaoping's dramatic comeback and the Third Plenary Session of the Eleventh Central Committee of the CPC in 1978, the fate of these people seems to have changed completely. In the past few years they have been able to wield considerable influence on the new policies and laws. One should always remember, however, that because of this group's small number and because of their enduring scars their impact on the overall policy is not likely to be overwhelming.

\section{IV}

\section{Integration: Prospects of Various Groups}

As mentioned earlier, in recent years the "bosses" are being replaced in ever-increasing numbers by the rank and file. This process is, of course, not a random one. The traditional seniority system still plays an important role while the seemingly resolute policy of the present Politbureau is to bootstrap more and more younger people into the policymaking machine. The promotional pattern is relatively simple now because of the necessary adoption of the somewhat radical policy that permits only people under a certain age to be promoted to a given position. This is done in order to realize a fast change in the composition of the upper level state machine. Since this policy is only remedial, it may not become a permanent policy in the face of the traditional respect for age and experience.

For our specific purposes, many “juniors" are being promoted into the positions otherwise logically expected to be held by the "seniors." Although the WPS "sophomores" have to wear the scarlet letter of the Cultural Revolution, and have the burden of overcoming the so-called "congenital deficiency" 46 in their education, quite a few of them nonetheless have already distinguished themselves (either politically or professionally) among their peers in other groups. The freshmen, as Chairman Mao used to say, are like "the rising sun between eight and nine o'clock in the morning." They still have a long way to go before their strength as a group can be taken seriously. But in the long run, the freshmen, together with the juniors, are the two most important factors in the whole policymaking process.

46. This brazenly offensive term is frequently used by the Chinese media to describe the WPS students. 


\section{THE IMPACT}

Now that one knows these people better, it is easier to realize that they are really multi-faceted living individuals rather than a "crack-free iron plate" (as the Chinese would describe a group of politically identical people). It should also be clear that they are not only capable of becoming one's adversaries, but can also be one's good friends, even if Americans may feel threatened by their beliefs (as the Chinese sometimes are by American motives). Before one sets out to find the many common points between "us" and them, however, one should first explore the common points among the Chinese which as a whole are bound to have a tremendous impact on the decisionmaking process in the legal and foreign economic relations fields in China.

The impact of their thinking manifests itself in roughly four different but intermittently related areas: political, economic, legal, and cultural effects.

\section{A. The Political Effect}

In China, the English word "political" is used for most purposes as the equivalent of the word "ideological." 47 Ideology has always played, and still plays, one of the major roles in many decisionmaking processes. This is so not only because of the "communistic" nature of the state machine and its political and economic structures, but also because of the traditional Chinese doctrine of zhengming ("rectification of names," or, a thing is what you call it). Confucius says ". . . to say or to do anything right, you must have a right theory under a legitimate name." To every ruler in Chinese history, the establishment of his/her dynasty's (or once the dynasty is established, his/her own era's) name is among the most important things. Once the name is chosen and "gilded" (meaning that nobody else could use that name anymore), a theory must be sanctioned by the emperor to guide the daily activities of the whole country. As time passes by, this ritual of zhengming has become so deeply ingrained in people's heads that they always expect a theory to accompany a change.

Although individually different groups of lawyers and businessmen in China may have different beliefs or attitudes, as a whole they share some basic ideological characteristics regardless of their background.

First of all, politics (read: ideology) is a "concentrated reflection of the economic structure"; it is the commander, the soul; it results from the economy and serves the economy but then rises above the economy and commands it. ${ }^{48}$ Therefore, although the communist ideal is to realize eventually a happy life (mostly an economic goal) for everyone, once an ideal is produced by an economic desire, it becomes independent (a political idea/ideological theory) and starts to command every aspect of economic life, including trade with foreign nations. This does not mean, however, that

47. These two terms are used interchangeably in this article, unless context dictates otherwise.

48. These are the words of Lenin and Mao in their numerous articles on basic Marxist theories. 
politics is always a higher consideration. According to Marxist dialectical materialism, politics can give way to economic considerations when it is, in the long run, for the benefit of the ultimate "grand objective" (meaning the realization of a global communist society). Therefore, it is not only perfectly acceptable, but also justifiably necessary to use "revolutionary double dealing" in the face of "counter-revolutionary double dealings." 49 Ideological purity can be sacrificed for economic objectives, as Lenin did in implementing the New Economic Policy and making concessions to Western capitalists, and as China has done with its "open-door policy" and the proposition that a good cat is the one that catches mice, be it black or white (Deng Xiaoping's legendary motto). Therefore, China's Economic Reformation can seemingly do away with most of the buds of an ideal communist system (e.g., the egalitarian big pot system) in the Chinese agricultural society; therefore there has always been the debate regarding the separability of politics from the economy (or rather of the economy from politics) whenever the need to attach greater importance to the economy becomes urgent; therefore. .. . We can go on for pages in listing examples of Marxist dialectics, but the point is that although these past events appear to be typical economic decisions and events, all of these past events are, in the last analysis, politically oriented. It is no more true to claim that China has given up its Marxist ideology and taken the capitalist road ${ }^{50}$ than to proclaim that China is becoming a Western-style legalistic society. In conclusion, we must always bear in mind the ultimate political objective when evaluating decisionmaking on any level.

\section{B. The Economic Effect}

Like the word "politics," the word "economy" also has its specific meaning in the Chinese Communist vocabulary. When used by a Chinese in the professions concerned here, it connotes not only the productivity of a society, but also the well-being, the daily necessities, and, in general, anything that is not "politics" proper. For a long time in PRC history, the economy had been of secondary importance. "Politics" had always occupied the "commanding role" in the sixty-year history of the Chinese Communist Party's policies. A few years ago, however, "economy" suddenly gained a position seemingly equal to or even more important than that of politics. This phenomenon, of course, is not accidental, but rather a reaction to the perverse application of so-called "orthodox Marxism-Leninism" to the Chinese reality when the necessity of applying it no longer existed. According to dialectical materialism, one of the most important Marxist theories, the economy is the base of a society. Every other social phenomenon is built

49. Lenin, "On Tactics."

50. The Western press always seems ready to grasp any sign of China's taking the "capitalist road," even if the signs are very far-fetched. See supra note 11. 
upon it and is determined by its actions. ${ }^{51}$ Politics as a part of the superstructure is no exception. The "beauty" of Marxism, however, does not lie there. Once the superstructure is formed, it becomes independent and starts to assert "reaction" to the economic base, that is, to accelerate or decelerate the economy. That is why Marxists always emphasize the role of politics (including the control of the state machine and ideological/propaganda work). Since the Chinese Communist Party had to fight a long war both within and without its own camp, it is understandable that it had to emphasize politics more than economics most of the time, even if according to its own theory the relationship between the two was never reversed because of the war. Unfortunately, however, this emphasis on the theory of politics with respect to reaction has been subject to too many abuses in the history of PRC. Some quasi- or pseudo-Marxists (for example, the Gang of Four) tried (often successfully) to ignore "action" (the effect of the economic base on the superstructure) in favor of the superstructure's "reaction," which is after all only a second-order attribute of things in the Marxist model. Although the action of the economy may be ignored, its objective existence is not subject to the subjective will power of any person; and it will ultimately express itself in a more forceful way. As has been demonstrated by the changes in China in recent years, the reaction that resulted from the ignored active force of the economic structure (for example, the long material hardship people had suffered and the disastrous situation in the national economy) almost tipped over the whole superstructure. ${ }^{52}$ The ultimate borderline, nevertheless, was not passed, and the equilibrium was and is being restored.

The trend now is not towards a capitalist road, but towards a more flexible and, really, a more orthodox Marxist road, where the action of the economic base is well respected while the reaction force of the superstructure is carefully guided. In the more specific areas of foreign economic policies (trade and investment), the above proposition is more likely to be corroborated by what has been going on and what will happen in the future.

Specifically, the possibilities and problems are in two areas: domestic policymaking and the surrounding international climate. Despite these variables, however, there is always one constant to bear in mind: the nature of foreign economic policy in China.

(1) Foreign trade has always been and will always be statemonopolized. As we have discussed in the section on legal and foreign trade education, foreign trade and investment, though both components of the economy, are in a very special category. Because of the inevitable involvement of capitalist (sometimes monarchic and

51. K. Marx, The Outline of a Critique of Political Economy, in The Marx-Engels Reader 4 (R.C. Tucker ed.).

52. It was quite apparent around the end of the Cultural Revolution that the country seemed ready for any kind of drastic change, including a revolutionary war. The fast-paced reformation of recent years seemed to have released much of the seething discontent towards the government that was pent up during that decade of chaos. 
tribal) economy and its accompanying culture, they are much more politicized to the socialist country than other economic sectors. Foreign economic policies have been, therefore, a highly important part of the superstructure since the very beginning of the first socialist state. Marx did not address this problem because he apparently envisioned communism's arrival in the form of a "big bang theory," namely, an overnight victory of all the world proletariats over capitalism, hence making the need for foreign trade obsolete in a big communist family. Lenin, however, had to deal with a very different and more realistic situation. In the face of the imperial powers' imminent threat to strangle the Revolution, he ordered among other things "the monopolization of foreign trade by the Soviet state."53 A state-monopolized foreign trade system worked effectively in the effort to build up a strong, self-reliant economy (especially during the worldwide Great Depression). New China had a similar situation. The United States-led trade embargo contributed directly to China's one-sided trade pattern in the 1950's. The Soviet repudiation of all economic contracts and withdrawal of experts in the early 1960's only strengthened China's determination to be substantially self-reliant. A monopolized foreign trade in such a situation is, for China, far more preferable than a free trade policy. The world situation has changed much since then, but the underlying rationale for the policy is still there, especially that of the necessity and advantage of the planned economy. ${ }^{54}$ The question is, therefore, not whether there should be a centralized/monopolized foreign economic policy for China, but how this policy can be effectively carried out.

(2) As the history of China's foreign economic transactions shows, there are both internal and external problems. The internal problems can be summarized in one sentence: "When you grasp it, it dies; when you let it go, it runs rampant" (yitong jiu si, yifang jiu luan). This describes the chronic dilemma of the effort to manage foreign trade. When the early years of difficulties with the West were over, the central government felt the need for a more flexible trade policy in terms of exportable items, price, terms and conditions of contracts, and so on, in order to tap the local governments' initiatives which had been suppressed in the highly centralized system. Once they had the word, however, the local (mainly thirty provincial level) Foreign Trade Corporations ("FTC's") acted quickly to stretch the policy so that competition among the FTC's soon became uncontrollable. The resulting benefits to foreigners

53. The Ordinance for Nationalization of Foreign Trade, signed by Lenin, April 22, 1918.

54. The author does not intend in this article to argue for the apparent advantage (at least theoretically) of a planned economy but is assuming it only because it is, and for some time will be, the basic theory of the Chinese Government. 
were obvious: lower prices, greater choices, and better service. But this decentralization could have been disastrous for the planned economy. Therefore, the central government halted implementation of the new policy and rescinded the autonomy given the local FTC's, imposing, in some instances, more stringent controls than before. The lack of initiatives then caused inefficiency, and state trade plans would often fall short of being fulfilled. A need to remedy the situation necessitated a new policy, which might very well trigger another round of $s i$ (falling dead) and luan (running rampant). This cycle repeated itself for many years. In today's political and economic atmosphere that is so conducive to the open-door policy, one hopes to see a better solution for this problem. But it is still only a hope. One cannot say with certainty that China is out of the circle forever.

Externally, the problem is more complicated.

(1) The anti-dumping and countervailing policies of the industrialized countries ${ }^{55}$ together with the archaic COCOM/Chincom ${ }^{56}$ restrictions have hindered China's efforts to expand into the world market;

(2) The destruction of China's traditional trade channels by the new policies has created certain distrust. Specifically, many of China's old trade partners are disappointed by the sudden influx of their competitors, which has largely diminished their past monopoly; (3) Aid to third-world states has been reduced to a trickle. Loans are no longer interest-free, and payments for goods often must be made with hard currency. This strained not only the bilateral relationship but also China's long-held Marxist-Leninist internationalism;

(4) The somewhat conflicting theories of a state-monopolized foreign trade and investment mechanism and China's strong stance against challenges to its sovereign immunity may pose some problems when it comes to foreign loans and other credit-sensitive activities.

\section{VI \\ Conclusion}

Problems are abundant. Difficulties multiply. But the future is bright, since China is heading in the right direction.

55. The magnesium dumping case filed before the ITC in 1983 was a graphic example of the conflicts between the U.S. trade policy and the new Chinese policy to encourage domestic competition.

56. These are the Paris-based Coordination Committee for Export to Communist Countries and its China subcommittee. 


\section{A. The Legal Effect}

Law, being a component of the superstructure, is always considered a handy tool for the ruling class. Therefore it is inevitably included in the consideration of political effects. This proposition does not, however, refute the necessity of establishing at least some kind of "form" in order for the machine to function in a relatively predictable way. ${ }^{57}$ To most Chinese, the codes and statutes have a kind of strange attribute more similar to procedural law in the eyes of American lawyers. For Chinese, substantive law is always the ultimate sense of fairness and social justice which, for the most part, is reflected by the customs, practices, and usages of the Chinese society. The written law is only a form through which to realize justice. As long as justice is done, people are not bothered too much about the statutory basis of the judgment. To most Chinese, "due process" is totally unknown. To the legal profession, it is something desirable, rather than something indispensable. After all, even the substantive law is the codification of the Party's policy and political needs, ${ }^{58}$ which are subject to the changes of the policy and needs. Why, then, should one bother with procedural guarantees of the law?

This attitude led to legal nihilism in the late 1950's and total anarchy throughout the Cultural Revolution. Many people suffered from the abuse of power and the lack of a predictable law, but only some seem to have learned the lesson. It is encouraging to see today that everyone (almost) is talking about the necessity of establishing a complete legal system, but the majority of the legal profession is no doubt still being largely influenced by the remnants of its prior legal education and working experience. If one considers all this, it is no longer puzzling that the Director of the Judicial Committee to the People's Congress would say, in 1985, the same thing that was said thirty years ago, that our law should not be too specific lest it tie our hands and feet in the face of the quickly changing situation. ${ }^{59}$ Since the situation in China is changing fast, and it will probably remain this way for quite some time, it is not surprising then that most of the new laws will be "short and unspecific,"60 and others remain "tentative drafts" for years. ${ }^{61}$

\section{B. The Cultural Effect}

Given the length of time involved, evaluating the overall impact of Chinese culture on contemporary legal thinking is a daunting task. Here, the focus is only on the competition between the schools of thought known as Legalism and Confucianism. With brief exceptions, the Legalist School as a whole never occupied more than a subordinate position in Chinese academic

57. See Montesquieu, On the Spirit of Law, Book 1.

58. The Basic Issues of the PRC Civil Law 9 (1958).

59. Wang Hanbin, Speech in the People's Congress Regarding the Enactment of the Civil Code, People's Daily, March 7, 1985, at 1 .

60. Napoleon's words in reference to drafting laws and regulations.

61. Some of today's laws, most notably the Rules of Civil Procedure, are still "in trial use" years after their implemention. 
history, while Confucianism became more and more influential, finally becoming the orthodox academic theory. Despite their cold treatment in history, many Legalist ideas infiltrated the Chinese legal system and the mainstream of Chinese culture. Among its better known axioms was the proposition that severe punishment prevented crime. This belief is still held by many Chinese people today. Yet its most important proposition was repeatedly discredited and never really implemented until today. This is the proposition of "rule by law" (fazhi), as opposed to the more Confucian "rule by man" (renzhi). The two thousand years of "rule by man" have totally negated this great, but premature theory. It should be noted, though, that the Confucian-influenced feudal hierarchical structure ran counter to the millennial academic tradition of ceaselessly searching for balance and symmetry. To a Chinese, the everlasting commanding role of one person over all others without check should be asymmetrical. But somehow people accepted the explanation that the complementary counterpart of the emperor was the role of the ministers. Instead of having some formal establishment to check the limitless power of the emperor, the ministers were supposed to point out his "shortcomings." 62 Today's legal structure in China still more or less reflects this tradition. So long as criticisms are permitted, very few people will be bothered by the fact that there is no real institutionalized counterbalancing organ to the ruling party.

Reflected in legal remedies, the traditional peasant standards of fairness and the sense of justice (seen by some Westerners as primitive) are still widely recognized. Pecuniary damages are not at all encouraged unless specific performance is rendered impossible by circumstances. One who kills should be killed. Criminal sanction should relieve civil liability. ${ }^{63}$ Going into court is disgraceful conduct. Disputes are mostly mediated in the neighborhood. The state is the representative of the people (more exactly, the majority of the people). Therefore, state interests must be better protected than individual interests. When there is a dispute between the state and a private person concerning the ownership of property, the presumption is that the state owns it. ${ }^{64}$ All in all, two things are most important here: reaching consensus and the protection of the interest of the majority.

\section{VII}

\section{POSTSCRIPT}

China is a huge country, so huge that despite the fact that 95 percent of the population is ethnic Chinese (the Han), people there cannot possibly be homogeneous. The above discussion is only a crude attempt to categorize and analyze certain groups of people, so as to make it easier for Americans to

62. By the same token, the aforementioned politics/economy polemics also require this rationale.

63. By the written law, criminal sanctions may not relieve civil liability. But the written law does not and cannot change people's thinking overnight.

64. See Tong Rou, Zhao Zhongfu \& Zheng Li, An Introduction to Civil Law 107-110 (1982). 
put into perspective the thinking processes of these groups. It is not meant to be exclusive or conclusive-nothing could be. 
